\title{
Alzheimer's-Type Amyloidosis in Transgenic Mice Impairs Survival of Newborn Neurons Derived from Adult Hippocampal Neurogenesis
}

\author{
Laure Verret, ${ }^{1 \star}$ Joanna L. Jankowsky, ${ }^{2 \star}$ Guilian M. Xu, ${ }^{3}$ David R. Borchelt, ${ }^{3}$ and Claire Rampon ${ }^{1}$ \\ ${ }^{1}$ Centre National de la Recherche Scientifique, Centre de Recherches sur la Cognition Animale, Université Paul Sabatier, 31062 Toulouse, France, ${ }^{2}$ Division \\ of Biology, California Institute of Technology, Pasadena, California 91125, and ${ }^{3}$ Department of Neuroscience, McKnight Brain Institute, University of \\ Florida, Gainesville, Florida 32610
}

\begin{abstract}
Alzheimer's disease (AD) is characterized by severe neuronal loss in several brain regions important for learning and memory. Of the structures affected by $\mathrm{AD}$, the hippocampus is unique in continuing to produce new neurons throughout life. Mounting evidence indicates that hippocampal neurogenesis contributes to the processing and storage of new information and that deficits in the production of new neurons may impair learning and memory. Here, we examine whether the overproduction of amyloid- $\beta(\mathrm{A} \beta)$ peptide in a mouse model for AD might be detrimental to newborn neurons in the hippocampus. We used transgenic mice overexpressing familial AD variants of amyloid precursor protein (APP) and/or presenilin-1 to test how the level (moderate or high) and the aggregation state (soluble or deposited) of $\mathrm{A} \beta$ impacts the proliferation and survival of new hippocampal neurons. Although proliferation and short-term survival of neural progenitors in the hippocampus was unaffected by APP/A $\beta$ overproduction, survival of newborn cells 4 weeks later was dramatically diminished in transgenic mice with Alzheimer's-type amyloid pathology. Phenotypic analysis of the surviving population revealed a specific reduction in newborn neurons. Our data indicate that overproduction of $A \beta$ and the consequent appearance of amyloid plaques cause an overall reduction in the number of adult-generated hippocampal neurons. Diminished capacity for hippocampal neuron replacement may contribute to the cognitive decline observed in these mice.
\end{abstract}

Key words: hippocampal neurogenesis; Alzheimer's disease; dentate gyrus; transgenic mouse; amyloid precursor protein; presenilin 1

\section{Introduction}

It is now widely accepted that the mammalian brain continues to produce neurons throughout adult life. This capacity for continued neurogenesis originates from progenitor cells located in discrete brain regions including the subgranular zone (SGZ) of the hippocampal dentate gyrus (DG). Although thousands of new neurons are produced every day in the young vertebrate hippocampus (Cameron and McKay, 2001), continuing (albeit at a much lower level) throughout adulthood, the function of these cells remains unclear. Adult neurogenesis is confined to brain regions with a high degree of plasticity, suggesting that these

\footnotetext{
Received Dec. 22, 2006; revised May 9, 2007; accepted May 9, 2007.

This work was supported by grants from the France Alzheimer Association and the Singer-Polignac Foundation (L.V.), the Agence Nationale pour la Recherche and the Centre National de la Recherche Scientifique (C.R.), the McKnight Brain Institute (D.R.B.), the John Douglas French Alzheimer's Foundation (J.L.J.), the American Health Assistance Foundation (J.L.J.), and the National Institute on Aging (K01 AG26144-01 to J.L.J.). We thank Bob and Julie Switzer at NeuroScience Associates (Knoxville, TN) for providing the MultiBrain Array sectioning and advice on handling these large-format sections. We gratefully acknowledge Dennis Steindler and the McKnight Brain Institute for supporting the completion of our study.

*L.V. and J.L.J. contributed equally to this work.

Correspondence should be addressed to either of the following: Dr. Joanna L. Jankowsky, California Institute of Technology, M.C. 156-29, Pasadena, CA 91125, E-mail: jj2@caltech.edu; or Dr. Claire Rampon, UMR5169 Centre National de la Recherche Scientifique, Centre de Recherches sur la Cognition Animale, Université Paul Sabatier, 118, route de Narbonne, 31062 Toulouse Cedex 4, France, E-mail: rampon@cict.fr.

DOI:10.1523/JNEUROSCI.5564-06.2007

Copyright $\odot 2007$ Society for Neuroscience $\quad 0270-6474 / 07 / 276771-10 \$ 15.00 / 0$
}

neurons may provide a means for encoding new information (for review, see Aimone et al., 2006; Leuner et al., 2006; Lledo et al., 2006; Bruel-Jungerman et al., 2007). Consistent with a role in memory formation, several studies have reported correlative evidence that survival of newborn hippocampal neurons is enhanced by tasks requiring the hippocampus (Gould et al., 1999; Leuner et al., 2004; Olariu et al., 2005). Conversely, reduction in neurogenesis by a cytostatic agent or irradiation impairs associative hippocampal-dependent learning (Shors et al., 2001, 2002; Snyder et al., 2005; Saxe et al., 2006; Winocur et al., 2006).

Hippocampal neurogenesis decreases drastically during aging in rodents, and this decline in neurogenic capacity has been suggested to underlie cognitive impairments that accompany senescence (Kuhn et al., 1996; Kempermann et al., 1998). More severe reductions in neurogenesis might contribute to the early symptoms of Alzheimer's disease (AD), including the inability to acquire and store new information. $\mathrm{AD}$ is a progressive neurodegenerative disease characterized by selective damage of brain regions involved in learning and memory (Price et al., 1986). The major histological hallmarks of $\mathrm{AD}$ include senile plaques containing amyloid- $\beta(\mathrm{A} \beta)$ peptide, neurofibrillary tangles containing hyperphosphorylated tau, and progressive loss of neurons in specific areas of the brain. Little is currently known about how the onset and progression of AD affects hippocampal neurogenesis. Contrary to initial expectation, data from postmortem tissue sug- 
gest that the proliferation of hippocampal progenitors is increased in AD (Jin et al., 2004a). This heightened proliferation may occur in response to diminished survival of newborn cells: in vitro data suggest that $\mathrm{A} \beta$ and its aggregates may be toxic to new neurons (Haughey et al., 2002).

We sought to examine the impact of amyloid precursor protein (APP)/A $\beta$ overproduction on hippocampal neurogenesis using mouse models that represent two different stages in the progression of AD. Transgenic mice overexpressing APP encoding the Swedish mutation (APPswe) develop late-onset amyloid pathology (Borchelt et al., 1997). Coexpression of the exon 9-deleted variant of presenilin 1 (PS1dE9) dramatically exacerbates $\mathrm{A} \beta$ production and accelerates appearance of amyloid pathology (Jankowsky et al., 2004). Comparison of APPswe and APPswe/PS1dE9 models at an intermediate age allowed us to study neurogenesis in mice resembling presymptomatic $\mathrm{AD}$, free of plaques but destined to develop disease (APPswe), versus animals resembling late-stage $\mathrm{AD}$ with significant amyloid pathology (APPswe/PS1dE9). These models allowed us to test how the amount of $\mathrm{A} \beta$ (moderate or high) and its aggregation state (soluble or deposited) impact proliferation, survival, and differentiation of newborn hippocampal cells thought to be critical for the cognitive functions lost in $\mathrm{AD}$.

\section{Materials and Methods \\ Transgenic mice}

Two lines of transgenic mice were used for this study. Line C3-3 expresses chimeric mouse APP with the Swedish mutation K670N/M671L and humanized A $\beta$ domain (Borchelt et al., 1996, 1997). Line S-9 expresses the exon 9-deleted variant of human PS1 (Lee et al., 1997; Jankowsky et al., 2004). Both transgenes are active in the CNS under the control of the mouse prion protein promoter. Each line was originally made by injection of $\mathrm{C} 3 \mathrm{HeJ} \times \mathrm{C} 57 \mathrm{BL} / 6 \mathrm{~J} \mathrm{~F} 2$ hybrid oocytes and maintained by mating transgene-positive animals with nontransgenic (NTG) C3/B6 F1 hybrids (The Jackson Laboratory, Bar Harbor, ME) for several generations. Both lines were subsequently backcrossed for 9-11 generations to be congenic on the C57BL/6J background. Mice for this study were generated from a final backcross of double-transgenic C3-3 APPswe B6n11/S-9 PS1dE9 B6n9 males with NTG C57BL/6J females to yield B6n10 offspring.

\section{5-Bromo-2-deoxyuridine injection and tissue preparation}

Eighty male mice derived from the two transgenic lines described above were used for this study. Four genotypes were generated from the final APP/PS1 male $\times$ C57BL/6J female backcross (APP/PS1, APP, PS1, and NTG); we examined 20 mice of each genotype. Starting at 6 months of age, all mice received an intraperitoneal injection once daily for 12 consecutive days with $50 \mathrm{mg} / \mathrm{kg}$ 5-bromo-2-deoxyuridine (BrdU; Sigma, St. Louis, $\mathrm{MO}$ ) dissolved in $0.9 \% \mathrm{NaCl}$. One day after the final injection, half of the mice were anesthetized and perfused transcardially with PBS, followed by $4 \%$ paraformaldehyde. The remaining animals were similarly perfused $30 \mathrm{~d}$ later.

Brains were then postfixed overnight in $4 \%$ paraformaldehyde at $4^{\circ} \mathrm{C}$ and cryoprotected with $30 \%$ sucrose. One hemisphere from each animal was used for analysis. Hemibrains were embedded 25 per block in a solid matrix, and coronal sections ( $40 \mu \mathrm{m}$ thick) were cut throughout the rostrocaudal extent of the hippocampus (MultiBrain processing by NeuroScience Associates, Knoxville, TN). Sections were stored in cryoprotectant at $-20^{\circ} \mathrm{C}$ until use.

\section{A $\beta$ immunochemistry}

Free-floating multibrain sections were rinsed extensively in PBS containing $0.25 \%$ Triton $\mathrm{X}-100$ (PBST) before quenching endogenous peroxidases with $3 \% \mathrm{H}_{2} \mathrm{O}_{2}$ in $10 \%$ methanol/PBS. Sections were incubated in $100 \%$ formic acid for $1 \mathrm{~min}$ and washed twice with distilled water. They were blocked in PBST with 5\% normal goat serum (NGS) for $30 \mathrm{~min}$, followed by overnight incubation at room temperature in polyclonal rabbit anti-A $\beta$ peptide (Zymed, San Francisco, CA) diluted 1:1000 in
PBST with $0.1 \%$ sodium azide (PBST-Az) and 5\% NGS. The next day, sections were rinsed in PBST and incubated for $90 \mathrm{~min}$ at room temperature in biotinylated goat anti-rabbit antiserum (Vector Laboratories, Burlingame, CA) diluted 1:500 in PBST. Sections were again rinsed with PBST before being incubated for $90 \mathrm{~min}$ at room temperature in avidinbiotin-peroxidase complex (Elite kit; Vector Laboratories) diluted 1:500 in PBST. Peroxidase immunolabeling was developed for $10 \mathrm{~min}$ at room temperature in $0.05 \mathrm{M}$ Tris- $\mathrm{HCl}$ buffer, $\mathrm{pH}$ 7.6, containing $0.025 \% 3,3^{\prime}$ diaminobenzindine-HCl (DAB; Fluka, Buchs, Switzerland) and 0.003\% $\mathrm{H}_{2} \mathrm{O}_{2}$. The reaction was stopped by rinses in PBST-Az. Sections were mounted onto subbed slides, dehydrated through alcohols, and coverslipped.

\section{Ki67 immunohistochemistry}

Sections were rinsed extensively in PBST before overnight incubation at room temperature with rabbit anti-human Ki67 antibody (NCL-Ki67p; Novocastra Laboratories/Vision BioSystems, Newcastle upon Tyne, UK) diluted 1:500 in PBST containing 5\% NGS, 1\% bovine serum albumin (BSA), and $0.5 \%$ Tween 20 . The next day, sections were washed in PBST, blocked in PBST/NGS/BSA/Tween 20, and incubated for $90 \mathrm{~min}$ at room temperature in biotinylated goat anti-rabbit antiserum diluted 1:500 in PBST (Vector Laboratories). Sections were washed several times with PBST, before incubating with avidin-biotin-peroxidase complex diluted 1:400 in PBST. Peroxidase immunolabeling was developed for 10 min at room temperature in $0.05 \mathrm{M}$ Tris- $\mathrm{HCl}$ buffer, $\mathrm{pH}$ 7.6, containing $0.025 \% \mathrm{DAB}, 0.003 \% \mathrm{H}_{2} \mathrm{O}_{2}$, and $0.06 \%$ nickel ammonium sulfate. The reaction was stopped by two rinses in PBST-Az. Sections were mounted onto subbed slides, counterstained with Nuclear Fast Red (Vector Laboratories), dehydrated through alcohols, and coverslipped.

\section{BrdU immunochemistry}

For single labeling of BrdU, sections were rinsed extensively in PBST before quenching endogenous peroxidases. Then, sections were incubated in $2 \mathrm{~N} \mathrm{HCl}$ for $40 \mathrm{~min}$ at room temperature to denature DNA and neutralized in $0.1 \mathrm{~m}$ borate buffer, $\mathrm{pH}$ 8.5. Sections were blocked in PBST with $5 \%$ NGS for $30 \mathrm{~min}$, followed by overnight incubation at room temperature in monoclonal rat anti-BrdU (OBT-0030; Harlan Seralab, Loughborough, UK) diluted 1:400 in PBST-Az and 5\% NGS. The next day, sections were rinsed several times in PBST and incubated for $90 \mathrm{~min}$ at room temperature in biotinylated goat anti-rat antiserum (Vector Laboratories) diluted 1:400 in PBST. Sections were again rinsed with PBST before being incubated for $90 \mathrm{~min}$ at room temperature in avidinbiotin-peroxidase complex (Elite kit; Vector Laboratories) diluted 1:400 in PBST. Peroxidase immunolabeling was developed as above. Sections were mounted onto subbed slides, counterstained with Nuclear Fast Red (Vector Laboratories), dehydrated through alcohols, and coverslipped.

\section{Determination of cell phenotype by triple immunolabeling}

$\mathrm{BrdU} / \mathrm{NeuN} / \mathrm{S} 100 \beta$. Sections used for triple-immunofluorescent labeling of BrdU with markers of postmitotic neurons (NeuN) and astrocytes $(\mathrm{S} 100 \beta)$ were pretreated and denatured as above before being blocked in a mix of $5 \%$ NGS and $0.1 \%$ BSA in PBST for $30 \mathrm{~min}$ at room temperature. Sections were then incubated overnight at room temperature in a mixture of anti-BrdU antibody (1:800), monoclonal mouse anti-NeuN (1: 5000, MAB377; Chemicon, Temecula, CA), and rabbit anti-S100 $\beta$ (1: 5000, 37a; Swant, Bellinzona, Switzerland) in PBST-Az containing 5\% NGS. The next day, sections were rinsed several times in PBST before being incubated for $90 \mathrm{~min}$ at room temperature in a mixture of secondary reagents: biotinylated goat anti-rat antiserum (1:400; Vector Laboratories), Alexa 488-conjugated highly cross-adsorbed goat anti-mouse IgG (1:250; Invitrogen, Carlsbad, CA), and Alexa 647-conjugated goat anti-rabbit IgG (1:250; Invitrogen) in PBST. Sections were rinsed again and finally incubated in streptavidin-tetramethylrhodamine isothiocyanate (TRITC; 1:1000 in PBST; Beckman Coulter, Fullerton, CA). Sections were mounted onto subbed slides, coverslipped using Mowiol, and stored at $4^{\circ} \mathrm{C}$.

$\mathrm{BrdU} / \mathrm{DCX} / \mathrm{NeuN}$. Sections used for triple-immunofluorescent labeling of BrdU with markers of immature neuronal precursors [doublecortin (DCX)], and postmitotic neurons (NeuN) were processed for antigen retrieval ( $10 \mathrm{~mm}$ sodium citrate buffer, $\mathrm{pH} 6.0$, for $30 \mathrm{~min}$ at $\left.95-100^{\circ} \mathrm{C}\right)$ 
before DNA denaturation as described above. Sections were then blocked with 2\% normal donkey serum, 1\% BSA, and 0.05\% Tween 20 in PBST for $60 \mathrm{~min}$. They were then incubated overnight at room temperature in a mixture of anti-BrdU (1:400) and goat anti-DCX (1:200, C-18; Santa Cruz Biotechnology, Santa Cruz, CA) in PBST. The next day, sections were rinsed and incubated for $90 \mathrm{~min}$ at room temperature in a mixture of biotinylated donkey anti-rat antiserum (1:1000; Jackson ImmunoResearch, Suffolk, UK) and Alexa 488-conjugated donkey anti-goat IgG (1:250; Invitrogen) in PBST. Sections were again rinsed in PBST and incubated for $90 \mathrm{~min}$ at room temperature in streptavidin-TRITC (1: $1000)$ in PBST. After rinses in PBST, sections were incubated for $24 \mathrm{~h}$ at $4^{\circ} \mathrm{C}$ in monoclonal mouse anti-NeuN (1:2000) in PBST. Sections were rinsed once more and finally incubated in Alexa 647-conjugated highly cross-adsorbed donkey anti-mouse IgG (1:250) in PBST.

In every study, incubation of brain tissue without the primary antibodies served as negative controls for immunohistochemistry.

Quantification of Ki67+ cells

Quantification of Ki67-immunoreactive (Ki67+) cells was conducted from a 1-in-12 series of peroxidase-labeled sections spaced at $480 \mu \mathrm{m}$ spanning the rostrocaudal extent of the hippocampus. Four mice from each genotype were sampled using DAB-developed sections stained for Ki67. Slides were coded before analysis; the experimenter was blind to genotype until all samples were counted. The corresponding surface area of the granule cell layer (GCL)/SGZ sampled for counting was measured using the Mercator stereology system (Explora Nova, La Rochelle, France). The reference volume was determined as the sum of the traced areas multiplied by the distance between sampled sections $(480 \mu \mathrm{m})$. The density of Ki67+ cells was then calculated by dividing the number of Ki67 + cells by GCL sectional volume. The total number of Ki67-positive cells was estimated by multiplying these densities by the reference volume.

\section{Quantification of BrdU+ cells}

Quantification of BrdU-immunoreactive (BrdU+) cells was conducted from a one-in-six series of peroxidase-labeled sections spaced at $240 \mu \mathrm{m}$ spanning the full rostrocaudal extent of the hippocampus. Slides were coded before analysis; the experimenter was blind to genotype until all samples were counted. Every BrdU+ cell within the GCL and adjacent SGZ, defined as a two-cell body-wide zone along the border between the GCL and the hilus, was counted through a $40 \times$ oil-immersion objective. Nuclei intersecting the uppermost focal plane were excluded from the count to avoid oversampling. The corresponding surface area of GCL/ SGZ sampled for counting was measured using the Mercator stereology system (Explora Nova). The reference volume was determined as the sum of the traced areas multiplied by the distance between sampled sections $(240 \mu \mathrm{m})$. The density of BrdU-positive cells was then calculated by dividing the number of BrdU-positive cells by GCL sectional volume. The total number of BrdU-positive cells was estimated by multiplying these densities by the reference volume.

\section{Measure of BrdU + cell migration within the GCL}

The migration of BrdU-immunoreactive cells was quantified in mice harvested $30 \mathrm{~d}$ after the final BrdU injection. Four mice were randomly chosen for analysis for each of three genotypes (APP, APP/PS1, and NTG). Fifty BrdU+ cells were counted for each animal using DABdeveloped sections stained for BrdU as described above. The GCL and underlying SGZ were divided into four separate regions (SGZ and inner, middle and outer thirds of the GCL). The fraction of BrdU+ cells found in each subregion of the DG was then calculated and compared between genotypes.

\section{Phenotypic quantification of BrdU+ cells}

To determine the relative distribution of phenotypes adopted by newborn cells after 30-42 d of survival, a one-in-six series of sections ( 240 $\mu \mathrm{m}$ spacing) through the rostrocaudal extent of the hippocampus was triple labeled for BrdU, NeuN, and $\mathrm{S} 100 \beta$ as described above. Five randomly selected animals were sampled from each of the four genotypes; fifty BrdU-labeled cells from each animal were randomly selected from the DG for phenotypic analysis. Coexpression of NeuN or S100 $\beta$ was assessed for each BrdU + cell using a confocal laser-scanning microscope (TCS SP2; Leica, Heidelberg, Germany). BrdU+ cells were analyzed for colocalization with either NeuN or $\mathrm{S} 100 \beta$ at $0.5 \mu \mathrm{m}$ step intervals over their entire $z$-axis using a $100 \times$ oil-immersion objective. Labeled cells were rotated in orthogonal planes ( $x$ and $y$ ) to verify double labeling. All analyses were done in sequential scanning mode to prevent crossover between channels. The mean percentage of BrdU + cells colabeled with NeuN or $S 100 \beta$ was calculated for each genotype. The mean number of cells for each phenotype was obtained by multiplying the average fraction for each phenotype by the individual BrdU + cell count for each animal (i.e., NeuN in NTG was calculated as the average product of $58.4 \% \times$ the total BrdU+ cell count for each NTG animal).

The relative number of mature and immature neurons among the surviving BrdU-labeled cell population was measured in APP/PS1 and NTG mice from a one-in-six series of sections triple labeled for BrdU, $\mathrm{NeuN}$, and DCX. Five randomly selected animals were sampled for each genotype; fifty BrdU + cells from each animal were randomly chosen in the DG for analysis. Coexpression of NeuN or DCX was assessed for each BrdU-labeled cell using a confocal laser-scanning microscope, and the mean number of cells for each phenotype was calculated as described above for NeuN/S100 $\beta$. Optical images were obtained for figures using Leica confocal software and processed with Adobe Photoshop 7.0 (Adobe Systems, San Jose, CA).

\section{Statistical analysis}

Cell count-by-genotype interactions were evaluated by one-way ANOVA using Systat version 11.0 software (Systat Software, Richmond, CA). Tukey's $t$ test was used for post hoc analysis to identify significant pairwise differences.

\section{Results \\ Amyloid pathology is specific to APP/PS1 mice at 6 months of age}

Transgenic mice expressing the Swedish variant of APP overproduce $A \beta$ and develop amyloid deposits late in life, between 20 and 24 months of age (Borchelt et al., 1996). The introduction of a second transgene associated with familial $\mathrm{AD}$, the exon 9 deletion mutation of PS1, dramatically increases the production of A $\beta$ and substantially accelerates the onset of amyloid pathology (Jankowsky et al., 2004). Plaques first appear in APPswe/PS1dE9 double-transgenic mice between 4 and 5 months of age and worsen with time. In contrast, the expression of PS1dE9 by itself causes no overt pathology and only slightly elevates the levels of endogenous $\mathrm{A} \beta$. We took advantage of this spectrum of $\mathrm{A} \beta$ production and amyloid onset to examine the effect of both moderate (APPswe) and high (APPswe/PS1dE9) overproduction of A $\beta$ on the proliferation and survival of newborn hippocampal cells. This approach allowed us to test the effect of APP/A $\beta$ on neurogenesis in mice of the same age that represented two different points in the progression of the pathology. As confirmed by $\mathrm{A} \beta$ immunohistochemistry, only double-transgenic APP/PS1 mice harbor amyloid pathology in the hippocampus at 6 months of age chosen for analysis (Fig. 1A). Neither NTG nor APP or PS1 single-transgenic mice show any amyloid pathology at this age (Fig. $1 B$ ).

Although loss of mature neurons is not a common feature of APP transgenic mice, the neurotoxic properties of $\mathrm{A} \beta$ in vitro (Yankner et al., 1989) may become apparent in vivo when presented to especially vulnerable cell populations such as newborn neural progenitors (Haughey et al., 2002). Our study therefore examined hippocampal progenitor proliferation, survival, and differentiation in APP and APP/PS1 transgenic mice to test the potential for $\mathrm{A} \beta$ neurotoxicity in vivo. 
Proliferation of hippocampal progenitor cells is unchanged by transgenic expression of mutant APP and/or PS1

To evaluate neural progenitor cell proliferation in the DG of APP, PS1, APP/PS1, and NTG animals, we counted the number of cells expressing the proliferation marker Ki67, which is present in cells during the active phases of the cell cycle $\left(G_{1}, S, G_{2}\right.$, and mitosis) but absent from cells in $G_{0}$ (Scholzen and Gerdes, 2000). We studied exclusively male mice to avoid the confounding effects of estrus in female animals and used transgenic lines that had been backcrossed for $>10$ generations onto the C57BL/6J background to limit variability caused by competing background strains.

We used nonbiased stereology to estimate the number of Ki67+ cells in each animal from a 1-in-12 series spanning the entire rostrocaudal extent of the hippocampus. The vast majority of cells labeled with Ki67 were found within the SGZ of each group, consistent with the location of self-renewing type 1 and 2 progenitor cells (Kempermann et al., 2004). We found that the number of $\mathrm{Ki} 67+$ cells was similar across the four genotypes (NTG, 474.0 \pm 68.9; PS1, $477.0 \pm$ 42.8; APP, $423.0 \pm 32.6$; APP/PS1, $510.0 \pm 75.9$ ) (Fig. 2). There were no significant differences between genotypes, indicating that transgene expression did not affect the proliferation rate of hippocampal progenitor cells in the DG.

\section{Short-term survival of newborn cells is not altered by overproduction of $\mathrm{A} \beta$}

In wild-type animals, the highest rate of newborn cell loss in the DG occurs within the first 2 weeks after cell division (Dayer et al., 2003; Kempermann et al., 2003). To determine whether the early survival of newborn hippocampal cells was affected by $\mathrm{A} \beta$ overproduction, we administered BrdU once daily for 12 consecutive days to label cells undergoing mitosis during this period. Early survival was assessed in mice killed $1 \mathrm{~d}$ after the final BrdU injection. Cells labeled in this manner represent a mixture of actively proliferating cells and committed postmitotic cells.

Newborn BrdU-immunoreactive (BrdU+) cells were distributed throughout the SGZ of the DG in all four genotypes (Fig. 3). The absolute number of BrdU + cells in the DG was comparable across the four groups of mice (NTG, $1559.4 \pm 82.6$; PS1, $1902.0 \pm 116.0 ;$ APP, $1684.0 \pm 217.7 ;$ APP/PS1, $1539.6 \pm 163.0)$ (Fig. 3, Table 1), indicating that transgene expression did not affect the immediate survival of newborn cells in the hippocampus. Thus, generation and short-term survival of adult newborn cells remains intact in APP and APP/PS1 mice despite higherthan-normal levels of $A \beta$ in both genotypes and widespread amyloid pathology in the latter.

Late survival of newborn cells is dramatically impaired in the hippocampus of double-transgenic APP/PS1 mice

After exiting the cell cycle, as many as $80 \%$ of the newly generated cells in the adult DG will die within 4 weeks (Kempermann et al., 2003). The surviving cells differentiate into neurons or glia. Whereas cell fate can be specified within $1 \mathrm{~d}$ after cell division, it is nearly 2 weeks before the processes of newborn neurons first reach their target field in CA3 and 4-7 weeks before they become functionally integrated into the hippocampal circuitry and indistinguable from older granule cells (Hastings and Gould, 1999; van Praag et al., 2002; Jessberger and Kempermann, 2003; Over-
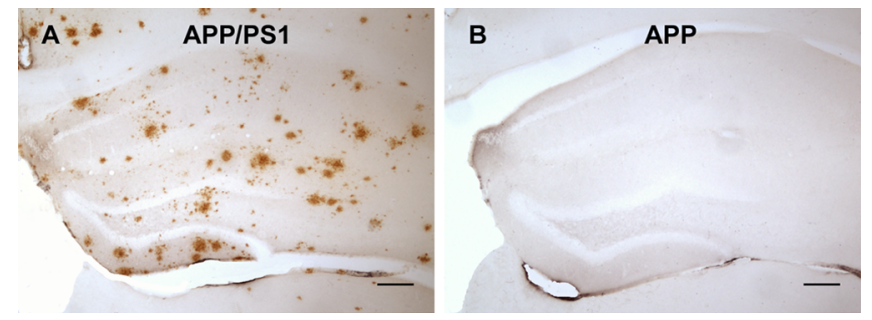

Figure 1. Amyloid plaques are specific to APP/PS1 mice at 6 months of age. Immunohistochemistry against $A \beta$ reveals widespread amyloid pathology in 6-month-old APP/PS1 mice $(\boldsymbol{A})$, whereas no $A \beta$ plaques are present in APP single-transgenic mice at this age $(\boldsymbol{B})$. Scale bars, 150 $\mu \mathrm{m}$.
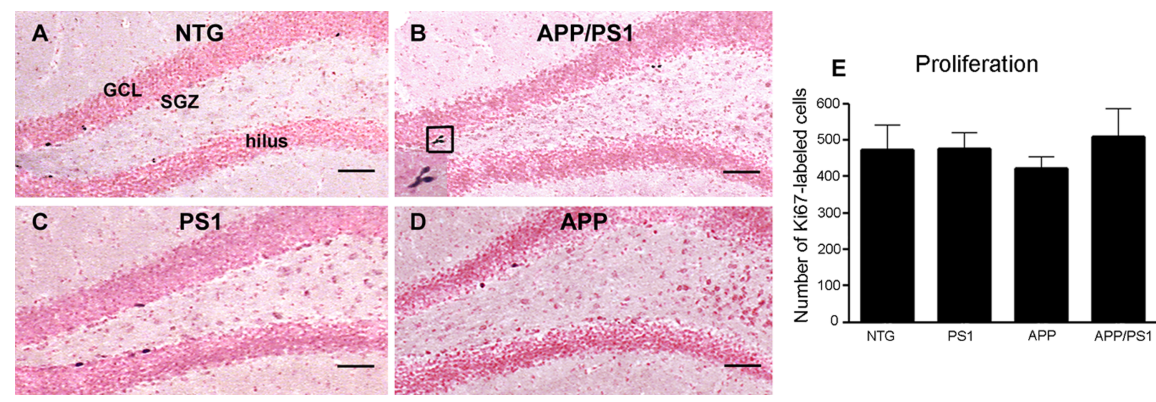
window, the formation of new hippocampal circuits and the survival of new neurons are sensitive to neuronal activity in the local environment (Tozuka et al., 2005; Ge et al., 2006; OverstreetWadiche and Westbrook, 2006; Tashiro et al., 2006). Given that altered hippocampal neurotransmitter levels in the $\mathrm{AD}$ brain are suggestive of changes in neuronal activity (Gsell et al., 2004; Lanctot et al., 2004), we evaluated the survival of newborn cells in the hippocampus of our transgenic mice during this critical window for survival.

Stereological analysis of BrdU+ cells in mice killed $30 \mathrm{~d}$ after labeling revealed a significant and specific decrease in the number of surviving newborn cells in APP/PS1 mice (APP/PS1, $181.8 \pm$ 26.9 vs NTG, $311.4 \pm 25.0 ; p<0.001$ ) (Fig. 4 , Table 1 ). In contrast, no significant differences in BrdU+ cell number were found between either group of single-transgenic mice and their NTG siblings (PS1, 331.2 \pm 17.0; APP, $234.4 \pm 15.7$ ). Thus, more newborn BrdU+ cells were eliminated in APP/PS1 mice than in any other genotype. Compared with the number of BrdU + cells present $1 \mathrm{~d}$ after the final injection, only $11.8 \%$ of newborn cells survived through the month in APP/PS1 mice compared with $20 \%$ in NTG mice.

Neurons are specifically reduced among surviving newborn hippocampal cells in mice overproducing $A \beta$

Our initial experiments measuring cell survival in the AD transgenic mice reveal that the number of newborn cells in the hippocampus is significantly diminished by 4 weeks after cell division in APP/PS1 double-transgenic mice. However, this analysis did not characterize which cell types were missing. Our next experiments therefore investigated the phenotype of the surviving newborn cells in the DG to determine whether the reduction in 

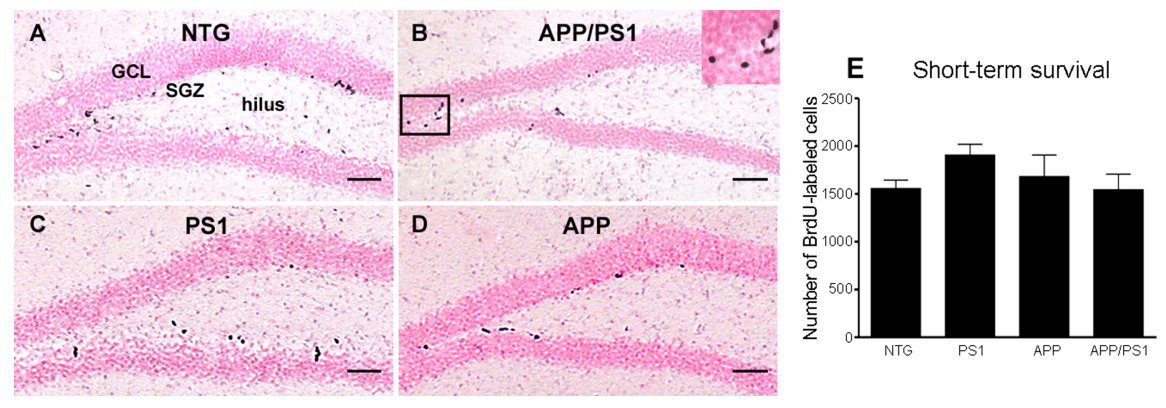

Figure 3. Short-term survival of newborn cells in the adult DG is not affected by APP/A $\beta$ overproduction. $A-D, 0$ ne day after the last of 12 daily BrdU injections, BrdU immunostaining in the DG is similar in all four genotypes. Nuclear Fast Red was used as a counterstain to identify morphological boundaries of the GCL and SGZ. Scale bars, $30 \mu \mathrm{m}$. $\boldsymbol{E}$, The absolute number of BrdU + cells in the DG is shown for each genotype (mean $\pm \mathrm{SEM} ; n=9-12$ for each group). Overproduction of APP/A $\beta$ had no significant effect on the number of BrdU + cells that were labeled 1-12 d earlier. Similarly, transgenic expression of mutant PS1 had no effect on early survival within the DG, either alone or when coexpressed with APPswe.
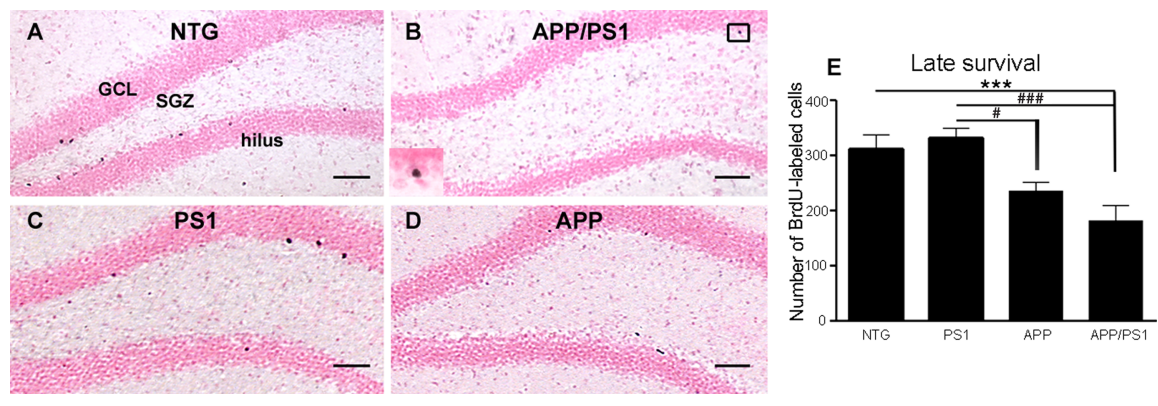

Figure 4. Late survival of newborn cells in the adult DG is dramatically reduced in APP/PS1 mice. $A-D$, Thirty days after the final BrdU injection, the number of BrdU-immunoreactive cells is noticeably diminished in the DG of double-transgenic APP/PS1 mice. Nuclear Fast Red was used as a counterstain to identify morphological boundaries of the GCL and SGZ. Scale bars, $30 \mu \mathrm{m}$. $\boldsymbol{E}$, The absolute number of BrdU + cells in the DG is shown for each genotype (mean $\pm S E M ; n=10-12$ per group). Overproduction of APP/A $\beta$ reduced the number of labeled cells surviving $30 \mathrm{~d}$ after the final BrdU injection in APP/PS1 double-transgenic animals $\left({ }^{* * *} p<0.001\right.$ vs NTG; ${ }^{\# \# ~} p<0.001$ vs PS1; ANOVA with Tukey's post hoc). Neither APP nor PS1 by themselves had any effect on the survival of newborn DG cells compared with NTG (APP vs PS1, $p<0.05$ ).

Table 1. Number of BrdU-immunoreactive cells in the dentate gyrus $1 \mathrm{~d}$ (short-term survival) and 4 weeks (late survival) after the last BrdU injection

\begin{tabular}{lll}
\hline & Number of BrdU+ cells & \\
\cline { 2 - 3 } Genotype & Short-term survival & Late survival \\
\hline NTG & $1559.4 \pm 82.6(n=10)$ & $311.4 \pm 25.0(n=10)$ \\
PS1 & $1902.0 \pm 116.0(n=9)$ & $331.2 \pm 17.0(n=10)$ \\
APP & $1684.0 \pm 217.7(n=12)$ & $234.4 \pm 15.7^{\#}(n=10)$ \\
APP/PS1 & $1539.6 \pm 163.0(n=10)$ & $181.8 \pm 26.9^{* * * * \# \# \#=12)}$ \\
\hline
\end{tabular}

Data are mean \pm SEM. Significance values indicated for individual pairs are as follows: ${ }^{* * *} p<0.001$ versus NTG; ${ }^{\# \# \# ~} p<0.001$ versus PS1; \# $p<0.05$ versus PS1 (ANOVA with Tukey's post hoc).

BrdU + cell number in APP/PS1 mice is caused by a specific loss of neurons or whether neurons and glia are equally susceptible to $\mathrm{APP} / \mathrm{A} \beta$ overproduction. We used triple immunohistochemistry to identify BrdU + cells in the DG and determined what fractions coexpressed either the postmitotic neuronal marker NeuN or the astrocytic marker $\mathrm{S} 100 \beta$.

Four weeks after the final injection of BrdU, a significantly lower fraction of BrdU + cells coexpressed the neuronal marker NeuN in APP single-transgenic and APP/PS1 double-transgenic mice compared with NTG controls (APP, 41.2 $\pm 4.4 \%$; APP/PS1, $36.0 \pm 3.9 \%$ vs NTG, $58.4 \pm 4.0 \% ; p<0.05$ and $p<0.01$, respectively) (Table 2 ). In absolute numbers (determined by multiplying the neuronal fraction by the total number of surviving BrdU + cells), both APP and APP/PS1 mice harbor significantly fewer newborn neurons $(\mathrm{BrdU}+/ \mathrm{NeuN}+/ \mathrm{S} 100 \beta-)$ than their NTG siblings (APP, $96.6 \pm 14.4$; APP/PS1, $65.5 \pm 7.6$ vs NTG, $181.9 \pm 6.5$; $p<0.001$ ) (Fig. 5, Table 2). Neuronal survival was not affected by expression of PS1 alone: neither the fraction nor the absolute number of BrdU+ cells coexpressing NeuN was significantly different between PS1 and their NTG siblings (Table 2). In contrast to the marked neuronal deficit in the APP and APP/PS1 mice, we found no difference in the fraction or number of surviving newborn glial cells (BrdU+/ NeuN-/S100 $\beta+$ ) across these genotypes. However, PS1 mice showed an increased number of newly generated astrocytes compared with NTG (Fig. 5, Table 2).

Evidence that loss of newborn neurons in APP/PS1 mice occurs relatively late in maturation

At least three different hypotheses could explain the decreased number of surviving new cells and the lower proportion of neurons among that population in our APP/ PS1 mice. First, there could be fewer newborn cells adopting a neuronal fate. Alternatively, a normal proportion of newborn cells may be choosing a neuronal fate but may take longer than normal to fully differentiate. Finally, there could be a normal proportion of cells adopting a neuronal fate, and these cells could be differentiating properly but then die as they mature. All three scenarios would result in the diminished number of postmitotic BrdU $+/ \mathrm{NeuN}+$ newborn neurons observed in our initial phenotypic analysis. To distinguish between these possibilities, we performed additional phenotypic analyses to measure the proportion of newborn cells that had become postmitotic neurons (marked by NeuN) compared with the population of immature neuronal precursors [marked by DCX (Couillard-Despres et al., 2005)]. DCX is a microtubule-stabilizing factor expressed early in neuronal differentiation. A subset of DCX+ cells remains proliferative as neural-restricted progenitors (Filippov et al., 2003; Kempermann et al., 2004). DCX expression is downregulated concomitantly with the appearance of the neuron-specific nuclear protein $\mathrm{NeuN}$ (Brown et al., 2003; Rao and Shetty, 2004).

Confocal analysis of triple BrdU/DCX/NeuN fluorescent immunolabeling confirmed the reduction in BrdU $+/ \mathrm{NeuN}+$ neurons (here marked as BrdU+/DCX $-/ \mathrm{NeuN}+$ ) in the APP/PS1 mice. Consistent with our previous experiment, we found that the proportion of postmitotic BrdU+/DCX $-/ \mathrm{NeuN}+$ neurons in APP/PS1 and NTG mice $(29.6 \pm 5.9$ vs $52.3 \pm 3.2 \% ; p<0.01)$ (Table 3) was similar to the proportion of $\mathrm{BrdU}+/ \mathrm{NeuN}+/$ S100 $\beta$ - cells measured previously in these mice (APP/PS1, $36.0 \pm 3.9 \%$; NTG, $58.4 \pm 4.0 \%$; see data above). Unlike our previous study of NeuN and GFAP, when double labeling for NeuN and DCX was measured, we found that the percentage of 
Table 2. Phenotypic distribution of BrdU-immunoreactive cells in the dentate gyrus 4 weeks after BrdU injection: astrocytes (S100 $\beta+$ ) versus neurons (NeuN + )

\begin{tabular}{|c|c|c|c|c|c|c|}
\hline \multirow[b]{2}{*}{ Genotype } & \multicolumn{3}{|c|}{ Fraction of BrdU + cells expressing } & \multicolumn{3}{|l|}{ Mean number of cells } \\
\hline & NeuN (\%) & $S 100 \beta(\%)$ & $\begin{array}{l}\text { Neither } \\
\text { marker (\%) }\end{array}$ & $\begin{array}{l}\text { BrdU }+/ \text { NeuN }+/ \\
\text { S100 } \beta-\end{array}$ & $\begin{array}{l}\text { BrdU +/NeuN }-/ \\
\text { S100 } \beta+\end{array}$ & $\begin{array}{l}\text { BrdU+/NeuN-/ } \\
\text { S100 } \beta-\end{array}$ \\
\hline NTG & $58.4 \pm 4.0$ & $12.8 \pm 2.8$ & $28.8 \pm 4.5$ & $181.9 \pm 6.5$ & $39.9 \pm 3.2$ & $89.7 \pm 7.1$ \\
\hline PS1 & $45.2 \pm 3.6$ & $20.5 \pm 4.7$ & $33.9 \pm 1.6$ & $149.7 \pm 9.7$ & $67.9 \pm 3.5^{\# \# \#}$ & $112.3 \pm 5.7$ \\
\hline APP & $41.2 \pm 4.4^{*}$ & $18.8 \pm 3.3$ & $39.4 \pm 4.6$ & $96.6 \pm 14.4^{* * *, \# \#}$ & $44.1 \pm 3.0$ & $92.4 \pm 6.2$ \\
\hline APP/PS1 & $36.0 \pm 3.9^{* *}$ & $21.2 \pm 6.1$ & $42.8 \pm 3.4$ & $65.5 \pm 7.6^{* * *, \# \#}$ & $38.6 \pm 5.7$ & $77.8 \pm 11.5^{\#}$ \\
\hline
\end{tabular}

BrdU-positive cells were phenotyped by colabeling with markers specific for neurons (NeuN) or astrocytes ( $S 100 \beta)$. The percentage of each phenotype as a fraction of the total BrdU + population (left columns) and the corresponding absolute number of cells (right columns) are indicated. Significance values indicated for individual pairs are as follows: ${ }^{*} p<0.05,{ }^{* *} p<0.01$, and ${ }^{* * *} p<0.001$ versus NTG; ${ }^{\#} p<0.05$ and ${ }^{\# \#} p<0.001$ versus PS1; \#\#\# $p<0.01$ versus NTG, APP, and APP/PS1 (ANOVA with Tukey's post hoc).

surviving BrdU + cells expressing neither marker was greater in the APP/PS1 $(59.6 \pm 7.5 \%)$ than in their NTG siblings $(39.5 \pm 2.3 \%$; $p<0.05)$. A known fraction of this BrdU+/DCX $-/ \mathrm{NeuN}-$ population reflects newly generated astrocytes $(\mathrm{BrdU}+/ \mathrm{NeuN}-/ \mathrm{S} 100 \beta+)$, which we have shown is not affected in the APP/PS1 mice (Table 2). The remaining population of BrdU+ cells is likely to include oligodendrocytes, microglia, and progenitor cells.

The main goal of the experiment was to examine the effect of APP/A $\beta$ overproduction on the percentage and mean number of surviving immature neurons $(\mathrm{BrdU}+/ \mathrm{DCX}+/ \mathrm{NeuN}-)$. As a percentage of the total BrdU + population, immature $\mathrm{BrdU}+/ \mathrm{DCX}+/ \mathrm{NeuN}-$ neurons were equally represented in APP/PS1 and NTG mice (APP/PS1, $10.8 \pm 3.4 \%$; NTG, $9.7 \pm 2.3 \%$ ) (Table 3). Recall, however, that there are significantly fewer total BrdU + cells surviving at this time point in the APP/PS1 animals than in their NTG siblings. When the corresponding mean number of BrdU+/DCX $+/ \mathrm{NeuN}-$ cells is calculated for each animal (by multiplying the fraction of BrdU $+/ D C X+$ cells by the total number of BrdU+ cells surviving at this time), we find significantly fewer immature neurons in APP/PS1 mice $(19.6 \pm 2.9)$ compared with NTG animals (30.2 $\pm 2.4 ; p<0.05)$ (Fig. 6, Table 3).

During adult neurogenesis, expression of DCX starts as neuroblasts are generated, peaks during the second week and is downregulated concomitantly with the appearance of the postmitotic neuronal marker NeuN (Brown et al., 2003; Rao and Shetty, 2004). This time course corresponds exactly with the BrdU injection and harvest schedule of our early survival experiments, which labeled newborn cells ranging in age from 1 to $13 \mathrm{~d}$ after division (Fig. 3). Given the absence of BrdU+ cell loss at this stage compared with the dramatic decrease in labeled cells measured $30 \mathrm{~d}$ later, our data suggest that the early $\mathrm{DCX}+$ stage is not affected by APP/A $\beta$ overexpression. Instead, the decrease in DCX + cells measured in cells 30-42 d after division likely occurred relatively late in the process of maturation, at the tail end of the DCX + stage. Our data show a much greater deficit in more mature newborn neurons in APP/PS1 mice that is best explained by the specific death of these cells as they approach neuronal maturation $(\mathrm{NeuN}+)$. Our data in mice overproducing
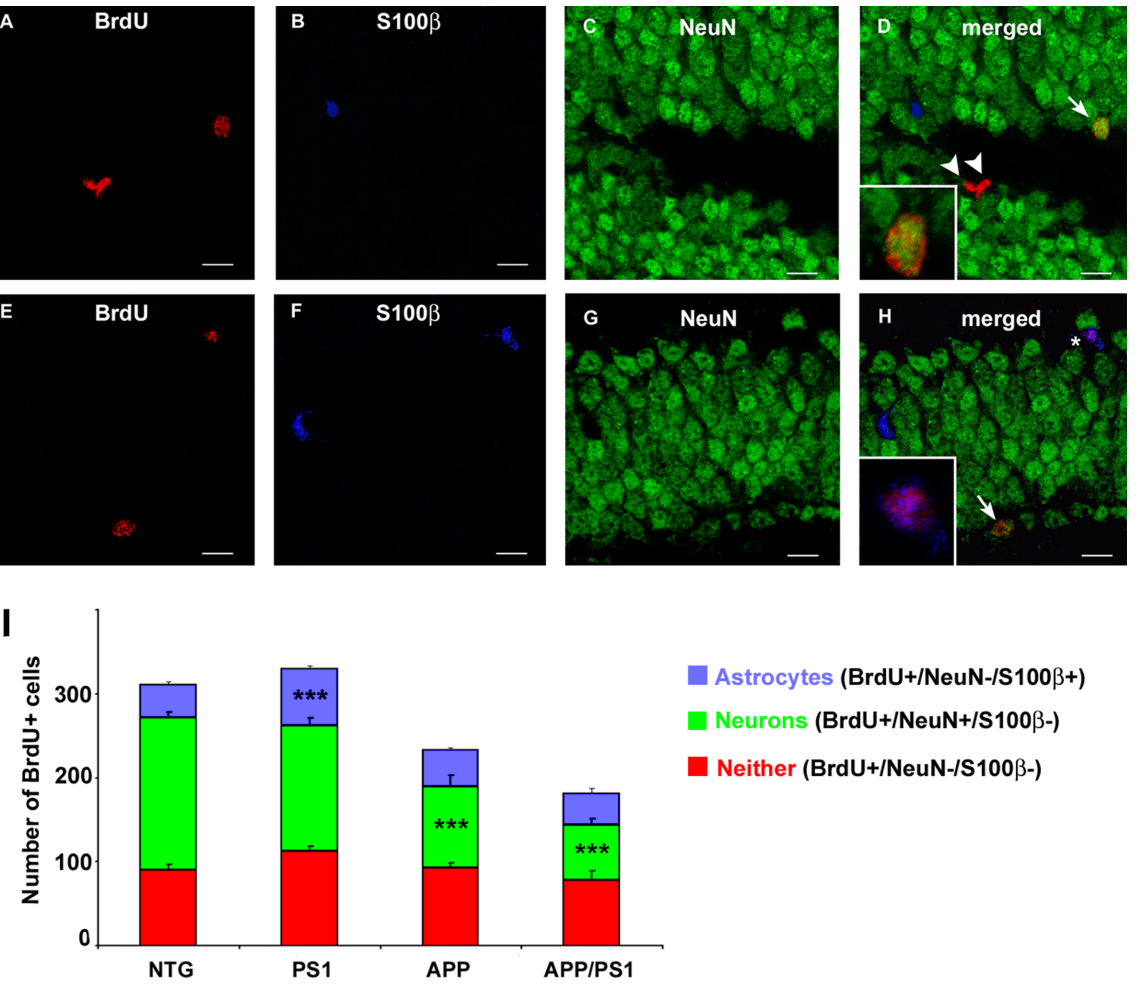

Neither (BrdU+/NeuN-/S100ß-)

Figure 5. Overproduction of APP/A $\beta$ specifically diminishes survival of newborn neurons in APP and APP/PS1 mice. $\boldsymbol{A}-\boldsymbol{C}, \boldsymbol{E}-\boldsymbol{G}$, Confocal analysis was used to score the coexpression of NeuN (green; $\boldsymbol{C}, \boldsymbol{G}$ ) and $S 100 \beta$ (blue; $\boldsymbol{B}, \boldsymbol{F}$ ) in BrdU + cells (red; $\boldsymbol{A}, \boldsymbol{E}$ ) from each genotype. $\boldsymbol{D}, \boldsymbol{H}$, Arrows in the merged images indicate BrdU $+/ \operatorname{NeuN}+$ neurons $(\boldsymbol{D}, \boldsymbol{H})$, the asterisk identifies a BrdU $+/$ S100 $\beta+$ astrocyte $(\boldsymbol{H})$, and arrowheads indicate BrdU + cells coexpressing neither marker $(\boldsymbol{D})$. I, Distribution of phenotypes in BrdU + cells by genotype. Compared with NTG, a significantly smaller number of BrdU + cells colabel with NeuN (green) in the hippocampus of both APP and APP/PS1 transgenic mice ( ${ }^{* * *} p<0.01$ vs NTG; ANOVA with Tukey's post hoc). In contrast, the number of newborn $\mathrm{S} 100 \beta+$ astrocytes (blue) and newborn cells expressing neither neuronal nor glial markers (red) is unchanged by overproduction of APP/A $\beta$. Error bars indicate SEM.

$\mathrm{APP} / \mathrm{A} \beta$ are thus most consistent with a specific loss of newborn neurons relatively late in the process of maturation.

\section{Newborn neurons migrate normally within the GCL of APP} and APP/PS1 mice

Recent studies suggest that the functional integration of newborn granule cells is sensitive to extrinsic signals in their local environment. Thus, proper migration within the GCL into an area with the requisite environment may be important for newborn neurons to mature and survive. To evaluate whether improper migration contributes to the reduced number of postmitotic newborn neurons in APP/PS1 mice, we examined the position of surviving BrdU + cells within the GCL. We found that migration of BrdU+ cells within the GCL did not vary between genotypes. In each group, the majority of 30- to 42-d-old BrdU+ cells were found within the SGZ (NTG, 34.3\%; APP, 42.3\%; APP/PS1, 
Table 3. Phenotypic distribution of BrdU-immunoreactive cells in the dentate gyrus 4 weeks after BrdU injection: postmitotic neurons (NeuN+) versus immature neuronal precursors $(D C X+)$

\begin{tabular}{|c|c|c|c|c|c|c|}
\hline \multirow[b]{2}{*}{ Genotype } & \multicolumn{3}{|c|}{ Fraction of BrdU + cells expressing } & \multicolumn{3}{|c|}{ Mean number of cells } \\
\hline & $\mathrm{DCX}(\%)$ & NeuN (\%) & $\begin{array}{l}\text { Neither } \\
\text { marker (\%) }\end{array}$ & $\begin{array}{l}\text { BrdU }+/ D C X+1 \\
\text { NeuN- }\end{array}$ & $\begin{array}{l}\text { BrdU }+/ \\
D C X-/ \text { NeuN }+\end{array}$ & $\begin{array}{l}\text { BrdU }+/ D C X-1 \\
\text { NeuN }-\end{array}$ \\
\hline NTG & $9.7 \pm 2.3$ & $52.3 \pm 3.2$ & $39.5 \pm 2.3$ & $30.2 \pm 2.4$ & $162.9 \pm 13.0$ & $123.0 \pm 9.8$ \\
\hline APP/PS1 & $10.8 \pm 3.4$ & $29.6 \pm 5.9^{* *}$ & $59.6 \pm 7.5^{*}$ & $19.6 \pm 2.9^{*}$ & $53.8 \pm 8.0^{* * *}$ & $108.6 \pm 16.0$ \\
\hline
\end{tabular}

BrdU-positive cells were phenotyped by colabeling with markers specific for postmitotic neurons (NeuN) or immature neuronal precursors (DCX). The percentage of each phenotype as a fraction of the total BrdU + population (left columns) and the corresponding mean number of cells is indicated. Significance values indicated for individual pairs are as follows: ${ }^{*} p<0.05,{ }^{* *} p<0.01$, and ${ }^{* * *} p<0.001$ versus NTG (ANOVA with Tukey's post hoc).
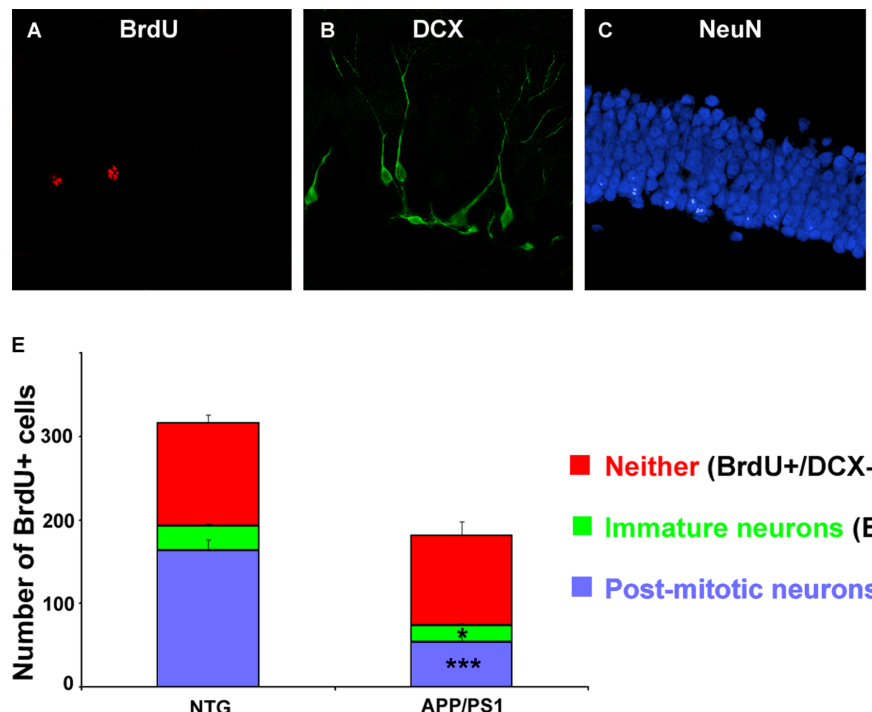

Figure 6. Overproduction of APP/A $\beta$ exacerbates cell death of newborn neurons as they approach maturity. $\boldsymbol{A}-\boldsymbol{C}$, Confocal analysis was used to score the coexpression of NeuN (blue; $\boldsymbol{C}$ ) and DCX (green; $\boldsymbol{B}$ ) in BrdU + cells (red; $\boldsymbol{A}$ ) in APP/PS1 and NTG mice. $D$, The arrowhead in the merged image identifies a BrdU $+/ D C X+/ N e u N-$ immature neuron. $E$, The number of BrdU + cells coexpressing the immature neuronal precursor marker DCX (green) is smaller in APP/PS1 than in NTG mice $\left(^{*} p<0.05\right.$; ANOVA with Tukey's post hoc). The decrease in BrdU + cells coexpressing the postmitotic neuronal marker NeuN (blue) in APP/PS1 mice is even more dramatic than the loss of DCX + cells $\left({ }^{* * *} p<0.001\right.$; ANOVA with Tukey's post hoc). In contrast, a similar number of newborn cells express neither marker (red) in APP/PS1 and NTG mice. Error bars indicate SEM.

$32.3 \%$ ) and the inner third of the GCL (NTG, 42.2\%; APP, 30.8\%; APP/PS1, 38.3\%). The remaining BrdU+ cells had reached the middle (NTG, 13.8\%; APP, 15.4\%; APP/PS1, 16.4\%) and outer (NTG, 9.8\%; APP, 11.5\%; APP/PS1, 12.9\%) thirds of the GCL in equal proportions across genotypes. Thus, the relative distribution of newborn cells within the DG was unaffected by $\mathrm{APP} / \mathrm{A} \beta$ overexpression, suggesting that other factors such as direct neurotoxicity, modification of the surrounding environment, or diminished production of requisite survival factors may be at play.

\section{Discussion}

In the current study, we show that hippocampal neurogenesis is dramatically impaired in transgenic mice overproducing $\mathrm{A} \beta$. We find that although proliferation and early survival of hippocampal progenitor cells are unaffected by transgenic APP/A $\beta$, the late survival of newborn cells $4-6$ weeks later is significantly diminished. Although recent reports have demonstrated altered neurogenesis in various models of $\mathrm{AD}$, our study makes an important advance in identifying the specific reduction in newborn neurons among the surviving population and demonstrating that these cells succumb to APP/A $\beta$ overproduction relatively late in maturation. Only $12 \%$ of newborn cells remain 1 month after cell division in APP/PS1 animals compared with 20\% in NTG mice. Of these cells, more than half express markers of postmitotic

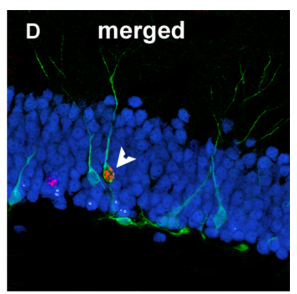

neurons in NTG mice compared with one-third in APP/PS1 animals. We also demonstrate that the amount and/or aggregation state of $A \beta$ is critical to this effect: neurogenesis is halved in predeposit mice but is even more dramatically reduced after the appearance of amyloid.

Previous studies of cultured primary neurons demonstrated that $\mathrm{A} \beta$ or its aggregates are neurotoxic in vitro (Yankner et al., 1989; Pike et al., 1993), and more recent work shows that this toxicity is concentration dependent (Haughey et al., 2002). Whereas this in vitro evidence supports a direct effect of $A \beta$ on neuronal survival, other factors may contribute to the impaired neurogenesis we observe in vivo. Microglial activation, loss of cholinergic input, and altered levels of growth factors are all associated with diminished adult neurogenesis, and each has been reported in transgenic models for AD (Benzing et al., 1999; Matsuoka et al., 2001; Savonenko et al., 2005; Wu et al., 2006). Additional studies are needed to determine whether newborn granule neurons are actively killed by $\mathrm{APP} / \mathrm{A} \beta$, or are unable to survive because of changes in the brain associated with $\mathrm{APP} / \mathrm{A} \beta$ overexpression.

Although several recent studies have examined hippocampal neurogenesis in other models of APP transgenic mice, ours is the first to use congenic lines that had been backcrossed to C57BL/6J for $>10$ generations. Careful control of the parental lines allowed us to examine effects of $\mathrm{APP} / \mathrm{A} \beta$ overexpression on a consistent genetic background. This strategy produces mice that derive $>99.8 \%$ of their genome from the backcross strain (C57BL6/J) but can retain up to $20 \mathrm{cM}$ of flanking sequence from the original parental lines (Bolivar et al., 2001; de Ledesma et al., 2006). Importantly, however, the use of congenic lines meant that the contribution of each parental strain is consistent from one mouse to the next ( $\sim 99.8 \% \mathrm{C} 57 \mathrm{BL} 6 / \mathrm{J}, 0.2 \% \mathrm{C} 3 \mathrm{HeJ})$. In contrast, past studies used hybrid or outbred backgrounds in which the proportion of two or more parental strains can vary significantly between animals (Haughey et al., 2002; Wen et al., 2002, 2004; Dong et al., 2004; Wang et al., 2004; Chevallier et al., 2005; Donovan et al., 2006). Because different strains display distinct proliferation, survival, and differentiation dynamics, there can be substantial variation in hippocampal neurogenesis depending on the genetic background (Kempermann et al., 1997; Hayes and Nowakowski, 2002). Our use of congenic mice avoided these confounds in demonstrating a strong effect of APP/A $\beta$ on hippocampal neurogenesis. 
In addition to genetic background, the various APP transgenes used in previous studies of hippocampal neurogenesis may contribute to their differing outcomes. Five studies using different APP transgenic or knock-in lines reported alterations of hippocampal neurogenesis in the mutant animals. The timing, direction, and nature of the changes varied substantially, including reduced proliferation and survival (Haughey et al., 2002), increased proliferation and neurogenesis (Jin et al., 2004b), reduced proliferation before and after onset of amyloid pathology (Dong et al., 2004), reduced proliferation specifically after onset of amyloid plaques (Donovan et al., 2006), and no change in proliferation unless mutant PS1 is coexpressed (Zhang et al., 2007). Our findings suggest yet another conclusion: diminished survival with no change in proliferation. Each report used mice expressing slightly different forms of APP under distinct promoters. The length, amount, location, and aggregation properties of $\mathrm{A} \beta$ can vary substantially between lines (Meyer-Luehmann et al., 2006), with potentially divergent effects on hippocampal neurogenesis.

Varying outcomes in neurogenesis have also been reported in mice expressing mutant forms of PS1. We demonstrated that expression of PS1dE9 alone did not affect hippocampal neurogenesis. In contrast, previous reports have described altered neurogenesis in other transgenic (Wen et al., 2004), hemizygous knock-in (Wang et al., 2004), and transgenically rescued knockout PS1 mice (Chevallier et al., 2005). Presenilins are mainly known as the catalytic subunits of $\gamma$-secretase (De Strooper et al., 1998; Haass and De Strooper, 1999; Wolfe et al., 1999), and PS1 mutations associated with AD clearly retain this function. In contrast, inherited mutations in PS1 may impact other interactions critical for alternative functions. For example, Chevallier et al. (2005) demonstrated that the dE9 mutation expressed in our PS1 transgenic mice does not alter $\beta$-catenin stability as dramatically as other PS1 variants. More recent data suggest that presenilins act as calcium leak channels in the endoplasmic reticulum (Tu et al., 2006) and that the PS1dE9 mutation leads to a gain of function, whereas other mutants induce loss of function. Aberrant activity of the dE9 variant in such nonenzymatic interactions may explain why neurogenesis is unaffected in our PS1dE9 mice and underlie the disparate data obtained from other PS1-modified mice.

Variations in labeling procedure used to assess hippocampal neurogenesis constitute another limitation to comparing reports in this field. The frequency, dose, and survival time after BrdU injection vary across studies, with many preparations labeling only a fraction of dividing cells (Cameron and McKay, 2001). Our injection protocol used multiple low-dose BrdU injections to label a reliable number of newborn cells from which to measure long-term survival. As a result of this multiday protocol, our measure of early survival, assessed $1 \mathrm{~d}$ after the final injection of BrdU, actually reflects a range of cells born 1-12 d earlier and includes both proliferative and postmitotic cells. The variation in cell age would have been of greater concern had we observed any change in the number of labeled cells at this time. Instead, our results show no difference between genotypes in this early surviving population. Additional analysis of actively dividing cells within this population using the mitotic marker Ki67 show no difference in precursor proliferation with overexpression of APP/ $\mathrm{A} \beta$. Together, these findings suggest that changes in neuronal number observed $30 \mathrm{~d}$ later occur long after cell division.

The timing of neuronal loss in our APP and APP/PS1 mice is consistent with the period during which newborn granule cells start extending processes into CA3 (Hastings and Gould, 1999; van Praag et al., 2002; Zhao et al., 2006), developing synaptic specializations of mature neurites (Zhao et al., 2006), and becoming functionally integrated into local neuronal networks (van Praag et al., 2002; Jessberger and Kempermann, 2003; Esposito et al., 2005; Ge et al., 2006; Kee et al., 2007). Survival during maturation may depend on the degree of functional integration into the pre-existing circuitry. Moreover, activity of surrounding neurons influences survival and maturation of newborn progenitors through tonic GABA activation even before they receive synaptic input (Ge et al., 2006; Overstreet-Wadiche and Westbrook, 2006). Both GABAergic and glutamatergic signaling required for successful maturation and integration of newborn neurons are compromised by late stages of AD (Gsell et al., 2004; Lanctot et al., 2004). Although not studied in our transgenic lines, the degradation of these neurotransmitter systems in other mouse models of AD (Bell et al., 2006) suggests loss of newborn neurons in our APP/PS1 mice may be caused by damage to the microenvironment required for their development and survival.

Recent findings have suggested that formation of some types of memory rely on the continuous production of new hippocampal neurons throughout adulthood (for review, see Leuner et al., 2006; Bruel-Jungerman et al., 2007). Although not all studies agree about which tasks are impaired, they collectively support the idea that continued adult neurogenesis is required to maintain the full range of hippocampal-dependent functions. Based on this observation, the reduction in neuronal survival observed in our APP and APP/PS1 mice likely has dramatic functional consequences. However, this deficit appears before learning impairments in standard- and episodic-like water maze tests (Savonenko et al., 2005), suggesting that diminished neurogenesis is one of several factors contributing to late-onset cognitive decline. Given this possibility, strategies to improve survival of newborn neurons, such as environmental enrichment or physical exercise, may help to delay cognitive decline in mouse models for AD. Accordingly, recent studies show that such interventions lead to significant behavioral improvement in APP and APP/PS1 mice (Arendash et al., 2004; Adlard et al., 2005; Jankowsky et al., 2005; Wolf et al., 2006; Costa et al., 2007).

In conclusion, our data indicate that neuronal replacement in the adult hippocampus is dramatically altered by Alzheimer's pathology. Our study demonstrates that overproduction and subsequent aggregation of $A \beta$ can severely limit the survival of newborn hippocampal neurons. That this deficit becomes more severe in mice with high levels of $\mathrm{A} \beta$ and fulminant plaque pathology suggests that there may be a period early in the disease during which hippocampal neurogenesis is still intact and might be preserved through therapeutic intervention.

\section{References}

Adlard PA, Perreau VM, Pop V, Cotman CW (2005) Voluntary exercise decreases amyloid load in a transgenic model of Alzheimer's disease. J Neurosci 25:4217-4221.

Aimone JB, Wiles J, Gage FH (2006) Potential role for adult neurogenesis in the encoding of time in new memories. Nat Neurosci 9:723-727.

Arendash GW, Garcia MF, Costa DA, Cracchiolo JR, Wefes IM, Potter H (2004) Environmental enrichment improves cognition in aged Alzheimer's transgenic mice despite stable beta-amyloid deposition. NeuroReport 15:1751-1754.

Bell KF, Ducatenzeiler A, Ribeiro-da-Silva A, Duff K, Bennett DA, Claudio Cuello A (2006) The amyloid pathology progresses in a neurotransmitter-specific manner. Neurobiol Aging 27:1644-1657.

Benzing WC, Wujek JR, Ward EK, Shaffer D, Ashe KH, Younkin SG, Brunden KR (1999) Evidence for glial-mediated inflammation in aged APP(SW) transgenic mice. Neurobiol Aging 20:581-589. 
Bolivar VJ, Cook MN, Flaherty L (2001) Mapping of quantitative trait loci with knockout/congenic strains. Genome Res 11:1549-1552.

Borchelt DR, Thinakaran G, Eckman CB, Lee MK, Davenport F, Ratovitsky T, Prada CM, Kim G, Seekins S, Yager D, Slunt HH, Wang R, Seeger M, Levey AI, Gandy SE, Copeland NG, Jenkins NA, Price DL, Younkin SG, Sisodia SS (1996) Familial Alzheimer's disease-linked presenilin 1 variants elevate Abetal-42/1-40 ratio in vitro and in vivo. Neuron 17:1005-1013.

Borchelt DR, Ratovitski T, van Lare J, Lee MK, Gonzales V, Jenkins NA, Copeland NG, Price DL, Sisodia SS (1997) Accelerated amyloid deposition in the brains of transgenic mice coexpressing mutant presenilin 1 and amyloid precursor proteins. Neuron 19:939-945.

Brown JP, Couillard-Despres S, Cooper-Kuhn CM, Winkler J, Aigner L, Kuhn HG (2003) Transient expression of doublecortin during adult neurogenesis. J Comp Neurol 467:1-10.

Bruel-Jungerman E, Rampon C, Laroche S (2007) Adult hippocampal neurogenesis, synaptic plasticity and memory: facts and hypotheses. Rev Neurosci 18:93-114.

Cameron HA, McKay RD (2001) Adult neurogenesis produces a large pool of new granule cells in the dentate gyrus. J Comp Neurol 435:406-417.

Chevallier NL, Soriano S, Kang DE, Masliah E, Hu G, Koo EH (2005) Perturbed neurogenesis in the adult hippocampus associated with presenilin-1 A246E mutation. Am J Pathol 167:151-159.

Costa DA, Cracchiolo JR, Bachstetter AD, Hughes TF, Bales KR, Paul SM, Mervis RF, Arendash GW, Potter H (2007) Enrichment improves cognition in $\mathrm{AD}$ mice by amyloid-related and unrelated mechanisms. Neurobiol Aging 28:831-844.

Couillard-Despres S, Winner B, Schaubeck S, Aigner R, Vroemen M, Weidner N, Bogdahn U, Winkler J, Kuhn HG, Aigner L (2005) Doublecortin expression levels in adult brain reflect neurogenesis. Eur J Neurosci 21:1-14.

Dayer AG, Ford AA, Cleaver KM, Yassaee M, Cameron HA (2003) Shortterm and long-term survival of new neurons in the rat dentate gyrus. J Comp Neurol 460:563-572.

de Ledesma AM, Desai AN, Bolivar VJ, Symula DJ, Flaherty L (2006) Two new behavioral QTLs, Emo4 and Reb1, map to mouse chromosome 1: congenic strains and candidate gene identification studies. Mamm Genome 17:111-118.

De Strooper B, Saftig P, Craessaerts K, Vanderstichele H, Guhde G, Annaert W, Von Figura K, Van Leuven F (1998) Deficiency of presenilin-1 inhibits the normal cleavage of amyloid precursor protein. Nature 391:387-390.

Dong H, Goico B, Martin M, Csernansky CA, Bertchume A, Csernansky JG (2004) Modulation of hippocampal cell proliferation, memory, and amyloid plaque deposition in APPsw (Tg2576) mutant mice by isolation stress. Neuroscience 127:601-609.

Donovan MH, Yazdani U, Norris RD, Games D, German DC, Eisch AJ (2006) Decreased adult hippocampal neurogenesis in the PDAPP mouse model of Alzheimer's disease. J Comp Neurol 495:70-83.

Esposito MS, Piatti VC, Laplagne DA, Morgenstern NA, Ferrari CC, Pitossi FJ, Schinder AF (2005) Neuronal differentiation in the adult hippocampus recapitulates embryonic development. J Neurosci 25:10074-10086.

Filippov V, Kronenberg G, Pivneva T, Reuter K, Steiner B, Wang LP, Yamaguchi M, Kettenmann H, Kempermann G (2003) Subpopulation of nestin-expressing progenitor cells in the adult murine hippocampus shows electrophysiological and morphological characteristics of astrocytes. Mol Cell Neurosci 23:373-382.

Ge S, Goh EL, Sailor KA, Kitabatake Y, Ming GL, Song H (2006) GABA regulates synaptic integration of newly generated neurons in the adult brain. Nature 439:589-593.

Gould E, Beylin A, Tanapat P, Reeves A, Shors TJ (1999) Learning enhances adult neurogenesis in the hippocampal formation. Nat Neurosci 2:260-265.

Gsell W, Jungkunz G, Riederer P (2004) Functional neurochemistry of Alzheimer's disease. Curr Pharm Des 10:265-293.

Haass C, De Strooper B (1999) The presenilins in Alzheimer's disease-proteolysis holds the key. Science 286:916-919.

Hastings NB, Gould E (1999) Rapid extension of axons into the CA3 region by adult-generated granule cells. J Comp Neurol 413:146-154.

Haughey NJ, Nath A, Chan SL, Borchard AC, Rao MS, Mattson MP (2002) Disruption of neurogenesis by amyloid beta-peptide, and perturbed neu- ral progenitor cell homeostasis, in models of Alzheimer's disease. J Neurochem 83:1509-1524.

Hayes NL, Nowakowski RS (2002) Dynamics of cell proliferation in the adult dentate gyrus of two inbred strains of mice. Brain Res Dev Brain Res 134:77-85.

Jankowsky JL, Fadale DJ, Anderson J, Xu GM, Gonzales V, Jenkins NA, Copeland NG, Lee MK, Younkin LH, Wagner SL, Younkin SG, Borchelt DR (2004) Mutant presenilins specifically elevate the levels of the 42 residue beta-amyloid peptide in vivo: evidence for augmentation of a 42 -specific gamma secretase. Hum Mol Genet 13:159-170.

Jankowsky JL, Melnikova T, Fadale DJ, Xu GM, Slunt HH, Gonzales V, Younkin LH, Younkin SG, Borchelt DR, Savonenko AV (2005) Environmental enrichment mitigates cognitive deficits in a mouse model of Alzheimer's disease. J Neurosci 25:5217-5224.

Jessberger S, Kempermann G (2003) Adult-born hippocampal neurons mature into activity-dependent responsiveness. Eur J Neurosci 18:2707-2712.

Jin K, Peel AL, Mao XO, Xie L, Cottrell BA, Henshall DC, Greenberg DA (2004a) Increased hippocampal neurogenesis in Alzheimer's disease. Proc Natl Acad Sci USA 101:343-347.

Jin K, Galvan V, Xie L, Mao XO, Gorostiza OF, Bredesen DE, Greenberg DA (2004b) Enhanced neurogenesis in Alzheimer's disease transgenic (PDGF-APPSw, Ind) mice. Proc Natl Acad Sci USA 101:13363-13367.

Kee N, Teixeira CM, Wang AH, Frankland PW (2007) Preferential incorporation of adult-generated granule cells into spatial memory networks in the dentate gyrus. Nat Neurosci 10:355-362.

Kempermann G, Kuhn HG, Gage FH (1997) Genetic influence on neurogenesis in the dentate gyrus of adult mice. Proc Natl Acad Sci USA 94:10409-10414.

Kempermann G, Kuhn HG, Gage FH (1998) Experience-induced neurogenesis in the senescent dentate gyrus. J Neurosci 18:3206-3212.

Kempermann G, Gast D, Kronenberg G, Yamaguchi M, Gage FH (2003) Early determination and long-term persistence of adult-generated new neurons in the hippocampus of mice. Development 130:391-399.

Kempermann G, Jessberger S, Steiner B, Kronenberg G (2004) Milestones of neuronal development in the adult hippocampus. Trends Neurosci 27:447-452.

Kuhn HG, Dickinson-Anson H, Gage FH (1996) Neurogenesis in the dentate gyrus of the adult rat: age-related decrease of neuronal progenitor proliferation. J Neurosci 16:2027-2033.

Lanctot KL, Herrmann N, Mazzotta P, Khan LR, Ingber N (2004) GABAergic function in Alzheimer's disease: evidence for dysfunction and potential as a therapeutic target for the treatment of behavioural and psychological symptoms of dementia. Can J Psychiatry 49:439-453.

Lee MK, Borchelt DR, Kim G, Thinakaran G, Slunt HH, Ratovitski T, Martin LJ, Kittur A, Gandy S, Levey AI, Jenkins N, Copeland N, Price DL, Sisodia SS (1997) Hyperaccumulation of FAD-linked presenilin 1 variants in vivo. Nat Med 3:756-760.

Leuner B, Mendolia-Loffredo S, Kozorovitskiy Y, Samburg D, Gould E, Shors TJ (2004) Learning enhances the survival of new neurons beyond the time when the hippocampus is required for memory. J Neurosci 24:7477-7481.

Leuner B, Gould E, Shors TJ (2006) Is there a link between adult neurogenesis and learning? Hippocampus 16:216-224.

Lledo PM, Alonso M, Grubb MS (2006) Adult neurogenesis and functional plasticity in neuronal circuits. Nat Rev Neurosci 7:179-193.

Matsuoka Y, Picciano M, Malester B, LaFrancois J, Zehr C, Daeschner JM, Olschowka JA, Fonseca MI, O’Banion MK, Tenner AJ, Lemere CA, Duff K (2001) Inflammatory responses to amyloidosis in a transgenic mouse model of Alzheimer's disease. Am J Pathol 158:1345-1354.

Meyer-Luehmann M, Coomaraswamy J, Bolmont T, Kaeser S, Schaefer C, Kilger E, Neuenschwander A, Abramowski D, Frey P, Jaton AL, Vigouret JM, Paganetti P, Walsh DM, Mathews PM, Ghiso J, Staufenbiel M, Walker LC, Jucker M (2006) Exogenous induction of cerebral betaamyloidogenesis is governed by agent and host. Science 313:1781-1784.

Olariu A, Cleaver KM, Shore LE, Brewer MD, Cameron HA (2005) A natural form of learning can increase and decrease the survival of new neurons in the dentate gyrus. Hippocampus 15:750-762.

Overstreet LS, Hentges ST, Bumaschny VF, de Souza FS, Smart JL, Santangelo AM, Low MJ, Westbrook GL, Rubinstein M (2004) A transgenic marker for newly born granule cells in dentate gyrus. J Neurosci 24:3251-3259. 
Overstreet-Wadiche LS, Westbrook GL (2006) Functional maturation of adult-generated granule cells. Hippocampus 16:208-215.

Pike CJ, Burdick D, Walencewicz AJ, Glabe CG, Cotman CW (1993) Neurodegeneration induced by $\beta$-amyloid peptides in vitro: the role of peptide assembly state. J Neurosci 13:1676-1687.

Price DL, Struble RG, Whitehouse PJ, Kitt CA, Cork LC, Walker LC, Casanova MF (1986) Alzheimer's disease: a multisystem disorder. Res Publ Assoc Res Nerv Ment Dis 64:209-214.

Rao MS, Shetty AK (2004) Efficacy of doublecortin as a marker to analyse the absolute number and dendritic growth of newly generated neurons in the adult dentate gyrus. Eur J Neurosci 19:234-246.

Savonenko A, Xu GM, Melnikova T, Morton JL, Gonzales V, Wong MP, Price DL, Tang F, Markowska AL, Borchelt DR (2005) Episodic-like memory deficits in the APPswe/PS1dE9 mouse model of Alzheimer's disease: relationships to beta-amyloid deposition and neurotransmitter abnormalities. Neurobiol Dis 18:602-617.

Saxe MD, Battaglia F, Wang JW, Malleret G, David DJ, Monckton JE, Garcia AD, Sofroniew MV, Kandel ER, Santarelli L, Hen R, Drew MR (2006) Ablation of hippocampal neurogenesis impairs contextual fear conditioning and synaptic plasticity in the dentate gyrus. Proc Natl Acad Sci USA 103:17501-17506.

Scholzen T, Gerdes J (2000) The Ki-67 protein: from the known and the unknown. J Cell Physiol 182:311-322.

Shors TJ, Miesegaes G, Beylin A, Zhao M, Rydel T, Gould E (2001) Neurogenesis in the adult is involved in the formation of trace memories. Nature 410:372-376.

Shors TJ, Townsend DA, Zhao M, Kozorovitskiy Y, Gould E (2002) Neurogenesis may relate to some but not all types of hippocampal-dependent learning. Hippocampus 12:578-584.

Snyder JS, Hong NS, McDonald RJ, Wojtowicz JM (2005) A role for adult neurogenesis in spatial long-term memory. Neuroscience 130:843-852.

Tashiro A, Sandler VM, Toni N, Zhao C, Gage FH (2006) NMDA-receptormediated, cell-specific integration of new neurons in adult dentate gyrus. Nature 442:929-933.

Tozuka Y, Fukuda S, Namba T, Seki T, Hisatsune T (2005) GABAergic excitation promotes neuronal differentiation in adult hippocampal progenitor cells. Neuron 47:803-815.

Tu H, Nelson O, Bezprozvanny A, Wang Z, Lee SF, Hao YH, Serneels L, De Strooper B, Yu G, Bezprozvanny I (2006) Presenilins form ER Ca2+ leak channels, a function disrupted by familial Alzheimer's disease-linked mutations. Cell 126:981-993.

van Praag H, Schinder AF, Christie BR, Toni N, Palmer TD, Gage FH (2002) Functional neurogenesis in the adult hippocampus. Nature 415:1030-1034.

Wang R, Dineley KT, Sweatt JD, Zheng H (2004) Presenilin 1 familial Alzheimer's disease mutation leads to defective associative learning and impaired adult neurogenesis. Neuroscience 126:305-312.

Wen PH, Shao X, Shao Z, Hof PR, Wisniewski T, Kelley K, Friedrich Jr VL, Ho L, Pasinetti GM, Shioi J, Robakis NK, Elder GA (2002) Overexpression of wild type but not an FAD mutant presenilin-1 promotes neurogenesis in the hippocampus of adult mice. Neurobiol Dis 10:8-19.

Wen PH, Hof PR, Chen X, Gluck K, Austin G, Younkin SG, Younkin LH, DeGasperi R, Gama Sosa MA, Robakis NK, Haroutunian V, Elder GA (2004) The presenilin-1 familial Alzheimer disease mutant P117L impairs neurogenesis in the hippocampus of adult mice. Exp Neurol 188:224-237.

Winocur G, Woitowicz JM, Sekeres M, Snyder JS, Wang S (2006) Inhibition of neurogenesis interferes with hippocampus-dependent memory function. Hippocampus 16:296-304.

Wolf SA, Kronenberg G, Lehmann K, Blankenship A, Overall R, Staufenbiel M, Kempermann G (2006) Cognitive and physical activity differently modulate disease progression in the amyloid precursor protein (APP)-23 model of Alzheimer's disease. Biol Psychiatry 60:1314-1323.

Wolfe MS, Xia W, Ostaszewski BL, Diehl TS, Kimberly WT, Selkoe DJ (1999) Two transmembrane aspartates in presenilin-1 required for presenilin endoproteolysis and gamma-secretase activity. Nature 398:513-517.

Wu ZL, Ciallella JR, Flood DG, O'Kane TM, Bozyczko-Coyne D, Savage MJ (2006) Comparative analysis of cortical gene expression in mouse models of Alzheimer's disease. Neurobiol Aging 27:377-386.

Yankner BA, Dawes LR, Fisher S, Villa-Komaroff L, Oster-Granite ML, Neve RL (1989) Neurotoxicity of a fragment of the amyloid precursor associated with Alzheimer's disease. Science 245:417-420.

Zhang C, McNeil E, Dressler L, Siman R (2007) Long-lasting impairment in hippocampal neurogenesis associated with amyloid deposition in a knock-in mouse model of familial Alzheimer's disease. Exp Neurol 204:77-87.

Zhao C, Teng EM, Summers RG, Jr., Ming GL, Gage FH (2006) Distinct morphological stages of dentate granule neuron maturation in the adult mouse hippocampus. J Neurosci 26:3-11. 